\title{
Bacteria associated with stranded cetaceans from the northeast USA and southwest Florida Gulf coasts
}

\author{
John D. Buck ${ }^{1}$, Neal A. Overstrom ${ }^{2}$, Geoffrey W. Patton ${ }^{3}$, Howard F. Anderson ${ }^{3}$, Jay F. Gorzelany ${ }^{3}$ \\ ' Department of Marine Sciences and Marine Research Laboratory, The University of Connecticut, Noank, Connecticut 06340, USA \\ ${ }^{2}$ Mystic Marinelife Aquarium, Sea Research Foundation, Inc., Mystic, Connecticut 06355, USA \\ ${ }^{3}$ Mote Marine Laboratory, 1600 Thompson Parkway, Sarasota, Florida 34236, USA
}

\begin{abstract}
A total of 64 stranded cetaceans from the northeast USA and southeast Florida Gulf coastlines were sampled for bacteria during the period 1984 to 1990 . Thirty-six individuals were dead when examined and 27 were alive but died shortly after stranding; one was released. Cultures were recovered from a variety of external and internal surfaces. Species of Vibrio were isolated from all Florida strandings; $V$. alginolyticus, $V$. parahaemolyticus, and $V$. damsela represented $35 \%$ of the total number of isolates (382). Vibrios were recovered from 10 individuals from the northeast; the 3 species above accounted for $17 \%$ of the total (139) and were most common from strandings between May and September. Other bacteria which represented $\geq 5 \%$ of the total number of isolates in one or both areas included Edwardsiella tarda, Morganella/Proteus/Providencia spp., Pseudomonas putrefaciens, and other pseudomonads. Some geographical differences were noted.
\end{abstract}

The causes of individual cetacean strandings remain poorly understood despite the popular and scientific interests which the incidents attract. Microbial disease is a possible explanation and some generalized information is available (Hall et al. 1971, Cordes 1982, Simpson \& Cornell 1983, Buck 1984, Baird et al. 1988, Martineau et al. 1988). In many cases, stranded carcasses have been too badly decomposed for adequate microbiological examination to establish one or more microbes as the etiological agent of death. The ultimate death of hundreds of stranded Atlantic bottlenose dolphins Tursiops truncatus along the eastern USA coast in 1987 may have involved several factors, including massive infection by opportunistic bacteria, particularly Vibrio spp., following immune suppression (Brody 1989, Smith 1990). The exact cause of death has not been shown unequivocally and hypotheses vary (Brody 1989, Geraci 1989, Smith 1990). However, it is recognized that species of Vibrio are extremely aggressive and dangerous to humans (Janda et al. 1988, West 1989). Vibrio species have been reported to cause death and illness in dolphins (Tangredi \& Medway 1980, Schroeder et al. 1985, Fujioka et al. 1988, Palmer et al. 1989) and are found in apparently healthy marine mammals (Buck \& Spotte 1986).

We sampled a large number of stranded cetaceans and present herein results of microbiological studies for individuals found in 2 different geographical areas. The data in checklist form may be valuable in assessing previous observations on stranding deaths and examination of future occurrences.

Materials and methods. A total of 64 cetaceans were sampled during the period 1984 to 1990 in 2 study areas; coastlines between Portland, Maine, and Atlantic City, New Jersey (29 individuals) and between Tampa and Ft. Myers, Florida (35 individuals). Thirtysix individuals were dead when examined and 27 were alive but died shortly after stranding; one was released. Several were maintained for a few hours in aquariums before subsequent death.

Samples for bacteriological analysis were collected using Culturette II swabs (Marion Scientific Co., St. Louis, Missouri) from a variety of external and internal sites, depending on the condition of the cetacean studied and whether or not a necropsy was performed. Most swabs from the northeast region were processed within $6 \mathrm{~h}$; some samples were overnight air-shipped, including all but 2 samples from Florida which were processed immediately upon receipt.

The following media were used for bacterial isolation: blood agar (Columbia agar base $+5 \%$ sheep blood), MacConkey agar, mannitol salt agar and thiosulfate-citrate-bile-sucrose (TCBS) agar. All media were from Difco Laboratories (Detroit, Michigan) or Becton Dickinson Microbiology Systems (Cockeysville, Maryland). The top section of each plate was swabbed directly. Streaking of the plate was com- 
Table 1. Bacteria isolated from stranded cetaceans

\begin{tabular}{|c|c|c|}
\hline Bacteria recovered & $\begin{array}{l}\text { Cetacean species and } \\
\text { location where isolated }\end{array}$ & Site of isolation ${ }^{c}$ \\
\hline Achromobacter/Acinetobacter/ & D. I. (CT) & bh, sl \\
\hline Alcaligenes/CDC IV E/ & G. m. (MA) & bh \\
\hline Moraxella/Pasteurella/ & L. al. (CT) & $b h, l u, v$ \\
\hline Pseudomonas sp. (AAACMPP) & T. t. $(F L, N J)$ & $a, b h, h b, l u, o, s l, s p$ \\
\hline Achromobacter/Acinetobacter/ & Z. c. (FL) & sl \\
\hline Alcaligenes/CDC IV E sp. & T t. $(F L)$ & gs \\
\hline \multirow[t]{2}{*}{ Achcromobacter/Pseudomonas sp. } & G. m. (MA) & bh \\
\hline & S. c. (NY) & bh \\
\hline Achromobacter $\mathrm{sp}$ & I t. $(F L)$ & 0 \\
\hline $\begin{array}{l}\text { Acinetobacter/Flavobacterium/ } \\
\text { Pseudomonas sp. }\end{array}$ & T. t. $(F L)$ & gs \\
\hline \multirow[t]{4}{*}{ Acinetobacter/Pseudomonas sp. } & D. 1. (CT) & $\mathrm{bh}$ \\
\hline & C. $m \cdot(M A A)$ & bin \\
\hline & P.m. $(F L)$ & bh \\
\hline & T t. (FL) & $\mathrm{a}, \mathrm{hb}, \mathrm{o}, \mathrm{sl}, \mathrm{sp}$ \\
\hline $\begin{array}{l}\text { Acinetobacter calcoaceticus } \\
\text { var. anitratus }\end{array}$ & T t. (FL) & $\mathrm{a}, \mathrm{gs}, \mathrm{o}$ \\
\hline $\begin{array}{l}\text { Acinetobacter calcoaceticus } \\
\quad \text { var. Iwoffii }\end{array}$ & T. t. $(\mathrm{FL})$ & o \\
\hline Acinetobacter sp. & G. m. (MA) & bh \\
\hline \multirow[t]{3}{*}{ Aeromonas hydrophila } & G. m. (MA) & $\mathrm{a}$ \\
\hline & L. al. (CT) & bh \\
\hline & T t. $(\mathrm{FL}, \mathrm{NJ})$ & $a_{1} b h, g s, m, o$ \\
\hline Alcaligenes sp. & $\mathrm{T}$ t. $(\mathrm{FL})$ & bh \\
\hline Chromobacterium sp. & T t. (FL) & gs \\
\hline \multirow[t]{4}{*}{ Citrobacter freundii } & G. m. (MA) & $\mathrm{a}$ \\
\hline & L. a. (CT) & a \\
\hline & S. c. (RI) & $\mathrm{a}$ \\
\hline & T. t. (FL) & $\mathrm{a}, \mathrm{bh}, \mathrm{gs}$ \\
\hline \multirow[t]{3}{*}{ Citrobacter sp. } & L. al. (CT) & bh \\
\hline & S. c. (RI) & bh \\
\hline & T. t. $(F L)$ & gs \\
\hline \multirow[t]{2}{*}{ Corynebacterium sp. } & L. al. (CT) & bh \\
\hline & T t. $(\mathrm{FL})$ & $g s, s l$ \\
\hline \multirow[t]{5}{*}{ Edwardsiella tarda } & D. 1. (CT) & bh \\
\hline & G. m. $(C T, M A)$ & $\mathrm{a}, \mathrm{bh}$ \\
\hline & L. a. $(\mathrm{MA}, \mathrm{RI})$ & $\mathrm{a}, \mathrm{ac}, \mathrm{bh}, \mathrm{h}$ \\
\hline & L. al. (CT) & $a, v$ \\
\hline & $\mathrm{T}$ t. $(\mathrm{FL})$ & a, gs, lu, o \\
\hline Enterobacter/Klebsiella sp. & $\mathrm{T}$ t. $(\mathrm{FL})$ & lu \\
\hline Enterobacter/Serratia sp. & L. a. $(\mathrm{MA})$ & $\mathrm{a}$ \\
\hline Enterobacter aerogenes & T. t. (FL) & $a, o$ \\
\hline \multirow[t]{2}{*}{ Enterobacter agglomerans } & L. a. (MA) & bh \\
\hline & T. t. (FL) & $0, s l$ \\
\hline \multirow[t]{3}{*}{ Enterobacter cloacae } & D. l. $(\mathrm{CT})$ & sl \\
\hline & T. t. (FL) & bh, gs \\
\hline & Z. c. (FL) & a \\
\hline \multirow[t]{5}{*}{ Escherichia coli } & D. d. (NY) & $\mathrm{a}, \mathrm{bh}$ \\
\hline & D. 1. (CT) & sl \\
\hline & G. m. (MA) & $\mathrm{a}, \mathrm{bh}$ \\
\hline & L. a. (MA) & $a, b h, h$ \\
\hline & $\mathrm{T}$ t. $(\mathrm{FL}, \mathrm{NY})$ & $\mathrm{a}, \mathrm{bh}, \mathrm{gs}, \mathrm{lu}, \mathrm{o}, \mathrm{sl}$ \\
\hline Escherichia hermanii & $T$ t. $(F L)$ & gs \\
\hline Flavobacterium/Cytophaga sp. & T t. (FL) & gs \\
\hline \multirow[t]{2}{*}{ Flavobacterium/Pseudomonas sp. } & G. m. $(\mathrm{MA})$ & bh \\
\hline & T t. (NJ) & sl \\
\hline \multirow[t]{2}{*}{ Flavobacterium meningosepticum } & P.p. (NY) & bh \\
\hline & $\mathrm{T}$ t. $(\mathrm{FL})$ & gs \\
\hline
\end{tabular}


Table 1 (continued)

\begin{tabular}{|c|c|c|}
\hline Bacteria recovered & $\begin{array}{l}\text { Cetacean species and } \\
\text { location where isolated }{ }^{a, b}\end{array}$ & Site of isolation ${ }^{c}$ \\
\hline \multirow[t]{3}{*}{ Flavobacterium sp. } & L. a. $(\mathrm{MA})$ & bh \\
\hline & S. c. (RI) & $\mathrm{a}$ \\
\hline & T t. $(\mathrm{FL})$ & bh, gs \\
\hline \multirow[t]{6}{*}{ Fluorescent Pseudomonas sp. } & D.d. $(\mathrm{NY})$ & it \\
\hline & G. m. (MA) & $\mathrm{bh}$ \\
\hline & L. a. (MA) & bh \\
\hline & P. m. $(F L)$ & bh \\
\hline & S. c. (NY) & a \\
\hline & T. t. (FL, NJ) & $\mathrm{a}, \mathrm{bh}, \mathrm{gs}, \mathrm{sl}$ \\
\hline Klebsiella oxytoca & T. t. (FL) & lu, sl \\
\hline \multirow{2}{*}{ Klebsiella pneumoniae } & G. m. (MA) & $\mathrm{a}$ \\
\hline & T t. (FL) & bh \\
\hline Klebsiella sp. & Z. C. $(F L)$ & sl \\
\hline \multirow[t]{3}{*}{ Micrococcus sp. } & G.m. $(\mathrm{MA})$ & $\mathrm{a}, \mathrm{bh}$ \\
\hline & S. c. (RI) & $\mathrm{a}$ \\
\hline & T. t. $(F L)$ & $\mathrm{a}, \mathrm{gs}, \mathrm{hb}, \mathrm{sl}$ \\
\hline Moellera wisconsensis & P. p. (CT) & bh \\
\hline Morganella morganii & T t. (FL) & $\mathrm{a}, \mathrm{bh}, \mathrm{hb}, \mathrm{gs}, \mathrm{lu}, \mathrm{o}$ \\
\hline \multirow[t]{2}{*}{ Pasteurella multocida } & D. l. (CT) & bh \\
\hline & I t. $(F L)$ & a \\
\hline Plesiomonas shigelloides & $T$ t. $(F L)$ & a, gs \\
\hline Proteus/Providencia sp. & $T$ t. $(F L)$ & $\mathrm{bh}, 0, \mathrm{sl}$ \\
\hline Proteus mirabilis & $\mathrm{T}$ t. $(F L)$ & $\mathrm{a}, \mathrm{bh}, \mathrm{gs}, \mathrm{o}$ \\
\hline Proteus penneri & $\mathrm{T}$ t. $(\mathrm{FL})$ & $\mathrm{a}$ \\
\hline \multirow[t]{2}{*}{ Proteus vulgaris } & G. m. $(\mathrm{ME})$ & $a, b h$ \\
\hline & $\mathrm{T}$ t. $(\mathrm{NY})$ & $a, b h, g s, o, s]$ \\
\hline \multirow[t]{2}{*}{ Proteus sp. } & G. m. $(\mathrm{ME})$ & a \\
\hline & $\mathrm{T}$ t. (FL) & bh \\
\hline Providencia rettgeri & $\mathrm{T}$ t. $(\mathrm{FL})$ & $\mathrm{a}, \mathrm{bh}, \mathrm{o}$ \\
\hline \multirow[t]{2}{*}{ Providencia stuartii } & G. m. (ME) & $\mathrm{a}$ \\
\hline & $T$ t. $(F L)$ & 0 \\
\hline Pseudomonas aeruginosa & $\mathrm{T}$ t. $(\mathrm{FL})$ & a, gs, lu \\
\hline \multirow[t]{3}{*}{ Pseudomonas maltophilia } & G. m. (MA) & bh \\
\hline & L. a. (MA) & bh \\
\hline & T t. $(\mathrm{FL})$ & $\mathrm{sp}$ \\
\hline \multirow[t]{5}{*}{ Pseudomonas putrefaciens } & D. 1. (CT) & $\mathrm{bh}$ \\
\hline & G. m. (ME) & a \\
\hline & L. a. $(R I)$ & 0 \\
\hline & L. al. (CT) & Y \\
\hline & T. t. $(\mathrm{FL}, \mathrm{NJ})$ & $\mathrm{a}, \mathrm{bh}, \mathrm{gs}, \mathrm{hb}, \mathrm{lu}, \mathrm{o}, \mathrm{sl}, \mathrm{u}$ \\
\hline \multirow[t]{6}{*}{ Pseudomonas sp. } & B. e. $(F L)$ & sl \\
\hline & D. 1. (CT) & sl \\
\hline & G. m. (MA) & $\mathrm{a}, \mathrm{bh}$ \\
\hline & P. m. (FL) & bh \\
\hline & P. p. (CT) & $y$ \\
\hline & T. t. $(\mathrm{FL})$ & $\mathrm{a}, \mathrm{bh}, \mathrm{gs}, 0, \mathrm{sl}$ \\
\hline Serratia liquefaciens & T. t. $(\mathrm{FL})$ & bh, lu \\
\hline Serratia rubidaea & T. t. (FL) & lu \\
\hline Serratia sp. & T. t. (FL) & a, sl \\
\hline Staphylococcus capitatus & $\mathrm{T}$ t. $(\mathrm{FL})$ & gs \\
\hline \multirow[t]{2}{*}{ Staphylococcus cohnii } & S. c. (RI) & $\mathrm{a}$ \\
\hline & T. t. (FL) & $\mathrm{bh}$ \\
\hline \multirow[t]{5}{*}{ Staphylococcus epidermidis } & B. e. $(F L)$ & bh \\
\hline & L. a. (MA) & a, bh \\
\hline & L. al. $(\mathrm{CT})$ & $\mathrm{v}$ \\
\hline & S. c. (RI) & $\mathrm{a}$ \\
\hline & T. t. (FL) & $\mathrm{bh}$ \\
\hline Staphylococcus hominis/saprophyticus & L. a. $(\mathrm{MA})$ & $\mathrm{a}, \mathrm{bh}$ \\
\hline
\end{tabular}


individuals) followed by $V$. parahaemolyticus (19), $V$. damsela (15), V. fluvialis (8), $V$. vulnificus (1), and $V$. mimicus (1). Vibrio occurrence is temperature-dependent with greatest numbers in seawater associated with higher water temperature (Janda et al. 1988). Consequently, it was not considered unusual that vibrios were recovered from Florida cetaceans where Gulf of Mexico waters would be warm enough year-round to support these bacteria.

In northeast USA waters, 29 individuals were sampled that stranded in all months except February and October. Vibrio spp. were recovered from 11 of these; 6 of the 8 that stranded between May and September were positive for Vibrio spp., whereas these organisms were only cultured from 5 of the 21 that stranded between October and April. These observations are consistent with the temperature relationships noted above, although 2 isolations of $V$. alginolyticus were from individuals that stranded in November and $V$. damsela was found in 2 strandings which occurred in November and December. Some species of Vibrio (e.g. $V$. cholerae) adhere to the surfaces of live copepods (Huq et al. 1984) and the survival and distribution of these bacteria may be affected by absorption to larger animals as well.

Table 2 considers, albeit arbitrarily, only those bacterial species representing more than $5 \%$ of the total number of isolations from each geographical area. In the northeast, 4 organisms comprised approximately the same representation; 10 to $12 \%$ (Edwardsiella tarda, Escherichia coli, various Pseudomonas species other than P. putrefaciens, Vibrio alginolyticus). Conversely, $V$. alginolyticus isolations were $19 \%$ of the Florida total (about twice that seen in northeast samples) and the other bacteria (or group) were $6 \%$ or less each. Two other species of Vibrio ( $V$. parahaemolyticus and $V$. damsela) were collectively $6 \%$ of the northeast isolates and $16 \%$ of those from Florida. Thus, the 3
Vibrio species in Table 2 were $16 \%$ of the total number of isolates from the northeast and $35 \%$ of the Florida total. The latter considered a larger number of isolates from the oral cavity and genital slit which could offer more surfaces for adsorption of bacteria. The data do indicate that vibrios are common in recently dead or debilitated cetaceans as well as in healthy specimens (Buck \& Spotte 1986) and colonize a wide variety of external and internal surfaces and organs. Several individuals from the Florida strandings showed the occurrence of several Vibrio spp. in internal organs which suggested rapid colonization by these bacteria. It should be noted that bacteria, other than vibrios, listed in Table 2 have also been found in stranded cetaceans in widely different geographical areas (e.g. Coles et al. 1978, Martineau et al. 1988, Walsh et al. 1988) and should be considered as opportunistic pathogens.

Unfortunately, necropsies could not be performed in all strandings reported here so that a more valid assessment of bacterial involvement could not be obtained. However, it is apparent from our observations that vibrios are common (often the most frequent isolate) in and on stranded cetaceans. This is probably not unusual because of the ubiquity of various Vibrio spp. in seawater but given the pathogenic potential of these organisms to humans (Janda et al. 1988, West 1989) it is clear that vibrios should be included in microbiological examination of any cetacean, whether it be wild, captive, or stranded. In addition, care should be exercised by all personnel handling marine animals because several species of Vibrio can produce severe bacteremia via cuts and punctures.

With respect to recent mass dolphin deaths, assessment of dinoflagellate toxin levels and bacteriological studies on live populations and at necropsy in future strandings may clarify ambiguities on the cause of mortality. The data provided here will be useful for comparative purposes.

Table 2. Bacteria representing $\geq 5 \%$ of the total number of isolates from each stranding area

\begin{tabular}{|c|c|c|c|c|c|c|}
\hline \multirow[t]{2}{*}{ Isolate } & \multicolumn{3}{|c|}{ Northeast USA } & \multicolumn{3}{|c|}{ Florida Gulf Coast } \\
\hline & $\begin{array}{c}\text { No. of } \\
\text { individuals } \\
(n=29)\end{array}$ & $\begin{array}{c}\text { No. of } \\
\text { isolates } \\
(n=139)\end{array}$ & $\begin{array}{l}\% \text { of } \\
\text { total }\end{array}$ & $\begin{array}{c}\text { No. of } \\
\text { individuals } \\
(\mathrm{n}=133)\end{array}$ & $\begin{array}{c}\text { No. of } \\
\text { isolates } \\
(n=382)\end{array}$ & $\begin{array}{l}\% \text { of } \\
\text { total }\end{array}$ \\
\hline Edwardsiella tarda & 12 & 16 & $12 \%$ & 8 & 10 & $3 \%$ \\
\hline Escherichia coli & 11 & 16 & $12 \%$ & 14 & 21 & $6 \%$ \\
\hline Morganella/Proteus/Providencia spp. & 2 & 5 & $4 \%$ & 19 & 38 & $10 \%$ \\
\hline Pseudomonas putrefaciens & 5 & 7 & $5 \%$ & 21 & 34 & $9 \%$ \\
\hline Other Pseudomonas spp. & 11 & 13 & $10 \%$ & 12 & 21 & $6 \%$ \\
\hline Vibrio alginolyticus & 8 & 14 & $10 \%$ & 28 & 74 & $19 \%$ \\
\hline V. damsela & 3 & 6 & $4 \%$ & 15 & 29 & $8 \%$ \\
\hline V. parahaemolyticus & 2 & 3 & $2 \%$ & 19 & 30 & $8 \%$ \\
\hline
\end{tabular}


Acknowledgements. The dedication of many persons involved in stranding occurrences is much appreciated. Dr J. L. Dunn (Mystic Marinelife Aquarium), R. Schoelkopf (Marine Mammal Stranding Center, Brigantine, NJ), and S. Sadove (Okeanos Ocean Research Foundation, Long Island, NY) were especially helpful. This research was supported in part by grants to J.D.B. from the Smithsonian Institution and the New York Zoological Society. Support for Mote Marine Laboratory personnel was provided primarily by the Florida West Coast Inland Navigation District and private donations. This is contribution no. 236 from the Marine Sciences Institute, The University of Conecticut and no. 77 of the Sea Research Foundation, Inc.

\section{LITERATURE CITED}

Bairci, $\bar{K}$. W., Langelier, $\bar{K}$. M., Stacey, $\longmapsto . J . ~(1988)$. Stranded whale and dolphin program of B. C. -1987 report. Brit. Col. Vet. Med. Assoc. Wildl. Vet. Rept. 1: 9-12

Brody, M. (1989). Explaining sea mammal deaths proves challenging. Am. Soc. Microbiol. News 55: 595-598

Buck, J. D. (1982). Nonstaining (KOH) method for determination of Gram reactions of marine bacteria. Appl. environ. Microbiol. 44: 992-993

Buck, J. D. (1984). Microbiological observations on two stranded live whales. J. Wildl. Dis. 20:48-50

Buck, J. D., Spotte, S. (1986). The occurrence of potentially pathogenic vibrios in marine mammals. Mar. Mamm. Sci. 2: $319-324$

Coles, B. M., Stroud, R. K., Sheggeby, S. (1978). Isolation of Edwardsiella tarda from three Oregon sea mammals. J. Wildl. Dis. 14: 339--341

Cordes, D. O. (1982). The causes of whale strandings. N. Z. Vet. J. 30: 21-24

Fujioka, R. S., Greco, S. B., Cates, M.B., Schroeder, J. P. (1988). Vibrio damsela from wounds in bottlenose dolphins Tursiops truncatus. Dis. aquat. Org. 4: 1-8

Geraci, J. R. (1989). Clinical investigation of the 1987-88 mass mortality of bottlenose dolphins along the U.S. central and south Atlantic coast. Final report to National Marine Fisheries Service, U.S. Navy, Office of Naval Research, and Marine Mammal Commission. University of Guelph, Ontario Veterinary College, Dept. of Pathology, Guelph, Ontario, Canada

Hall, J. D., Gilmartin, W. G., Mattsson, J. L. (1971). Investiga-

Responsible Subject Editor: M. D. Dailey, Long Beach, California, USA tion of a Pacific pilot whale stranding on San Clemente Island. J. Wildl. Dis. 7: 324-327

Huq, A., Small, E. B., West, P. A., Colwell, R. R. (1984). The role of plankton copepods in the survival and multiplication of Vibrio cholerae in the aquatic environment. In: Colwell, R. R. (ed.) Vibrios in the environment. John Wiley, New York, p. 521-534

Janda, J. M., Powers, C., Bryant, R. G., Abbott, S. L. (1988). Current perspectives on the epidemiology and pathogenesis of clinically significant Vibrio spp. Clin. Microbiol. Revs. 1: 245-267

Lemos, M. L., Toranzo, A. E., Barja, J. L. (1985). Modified medium for the oxidation-fermentative test in the identification of marine bacteria. Appl. environ. Microbiol. 49: $1541-1543$

MacDonell, M. T., Singleton, F. L., Hood, M. A. (1982). Diluent composition for use of API $20 \mathrm{E}$ in characterizing marine and estuarine bacteria. Appl. environ. Microbiol. 44: $423-427$

Martineau, D., Lagace, A., Beland, P., Higgins, R., Armstrong, D. Shugart, L. R. (1988). Pathology of stranded beluga whales (Delphinapterus leucas) from the St. Lawrence Estuary, Quebec, Canada. J. comp. Pathol. 98: 287-311

Palmer, C. J., Fujioka, R. S., Douglas, J. T (1989). Surveys of vibrios and other bacterial flora in the bottlenose dolphin. Abstracts of Annual Meeting, American Society for Microbiology, p. 286

Schroeder, J. P., Wallace, J. G., Cates, M. B., Greco, S. B. Moore, P. W. B. (1985). An infection by Vibrio alginolyticus in an Atlantic bottlenose dolphin in an open ocean pen. $J$ Wildl. Dis. 21: $437-438$

Simpson, J. G., Cornell, L. H. (1983). Diseases associated with stranding and captivity. In: Howard, E. B. (ed.) Pathology of marine mammal diseases, Vol.2. CRC Press, Boca Raton, p. 29-64

Smith, H. L., Jr (1990). Another hypothesis about dolphin deaths. Am. Soc. Microbiol. News 56: 249

Tangredi, B. P., Medway, W (1980), Post-mortem isolation of Vibrio alginolyticus from an Atlantic white-sided dolphin (Lagenorhynchus acutus). J. Wildl. Dis. 16: 329-331

Walsh, M. T., Beusse, D., Bossart, G. D., Young, W. G., Odell, D. K., Patton, G. W. (1988). Ray encounters as a mortality factor in Atlantic bottlenose dolphins (Tursiops truncatusd). Mar. Mamm. Sci. 4: 154-162

West, P. A. (1989). The human pathogenic vibrios - a public health update with environmental perspectives. Epidem. Inf. 103: 1-34

Manuscript first received: October 1, 1990 Revised version accepted: January 8, 1991 